\title{
A one-week introductory course in clinical biochemistry and research based on renal function testing in man
}

\author{
K. D. G. EDWARDS, ELIZABETH A. CURTIS, AND LYNN M. STOKER \\ From the Keith Kirkland Renal Unit, Medical Research Department, Kanematsu Memorial Institute, Sydney \\ Hospital, Sydney, NSW, Australia
}

SYNOPSIS A one-week introductory course in clinical biochemical and research techniques was devised to provide a brief but concentrated experience for interested persons. Urinary creatinine concentrations were measured to demonstrate acceptable degrees of precision of a method (coefficients of variation, $0 \cdot 5-2 \cdot 4 \%$ ), and to give confidence by favourable comparison with routine laboratory results (day 2, mean $0.95 \mathrm{vs} 0.94 \mathrm{mg} / \mathrm{ml}$ ). Subjects then submitted themselves to one-day renal function testing, and subsequently measured their own urinary acid-base parameters by autotitrimetry and glomerular filtration rates by spectrophotometry. The values obtained for the latter fell within the normal range (85-124\% of normal, corrected for age and surface area). Finally, statistical methods and a small desk-top computer were employed to compute linear regression equations, correlation coefficients, and t tests from the week's data. The course contained a number of features which stimulated learning, including active participation by the learner, and the use of meaningful materials to induce both desire for success and tolerance of mistakes.

A one-week introductory course in laboratory and research techniques was instituted in the Medical Research Department for the following reasons: first, to have available a means of teaching medical research skills and concepts to those who desired it; secondly, to condense the teaching activities into as short a time as possible; thirdly, to have available a way of initiating new members into the department. The course was found to be suitable for medical and scientific staff, including MD and MSc candidates, for undergraduate vacation scholars (medical and science students), and for medical laboratory technologists (qualified and trainees). In this instance the course was based on renal function testing, performed in the Keith Kirkland Renal Unit Laboratories. In practice, it has enabled an undergraduate vacation scholar (a second-year science student) to undertake and complete a research project in eight weeks (Pratt, McCredie, and Edwards, 1967), and a migrant clinical scientist to present a research paper on work done in the department at an Australasian congress less than six weeks after landing (Steele, Edwards, and Györy, 1968). A complete report on renal dysfunction in analgesic Received for publication 18 March 1971. nephropathy in man was published some months later (Steele, Györy, and Edwards, 1969).

We feel that this approach to teaching could be applied to any type of laboratory work, the tests being changed to suit individual laboratories' requirements.

\section{Materials and Methods}

The course has been successfully completed by many people, but the results for six were most readily available. These people had a variety of qualifications and undertook the course at different times, as follows: A.G., MB, BS, MRACP, January 1966; C.A., BSc hons, February 1966; R.G., BSc hons, February 1968; E.C., BSc, February 1968; J.C., AAIMLT, February 1968; and L.S., MLT in training, June 1967.

\section{Course Programme}

DAYS 1 AND 2

A brief introductory talk was given on the activities of the Medical Research Department (Kanematsu Memorial Institute Annual Report, 1965) and a 
tour of inspection of the department and introduction to research staff was made.

A demonstration was then given by the librarian on the use of the medical library, and on other ways of communication, for example, by requesting reprints or by reading up-to-date editions of textbooks (see Appendix). Reference card systems for filing information about scientific articles were discussed and a system of filing was begun.

A course of pipetting techniques in estimating urinary creatinine concentrations was undertaken to illustrate the need for precision and accuracy of measurements and to give confidence in pipetting and spectrophotometric methods (see Appendix).

At the end of the second day a talk was given on the washing and care of laboratory glassware.

\section{DAY 3}

The whole day was set aside for one-day renal function testing, which has been described in detail previously (Edwards, Stewart, Ashley, and Whyte, 1964) (see Appendix).

The new worker underwent these tests to learn by experience the variety of methods used in one day to screen patients quickly in the Medical Research Department, and, secondly, to provide a personal interest in the subsequent laboratory work. Comparison of the results obtained with each laboratory's established values for normal was also valuable as a suitable check or 'quality control' for the laboratory methods involved.

\section{DAY 4}

The value of quality control tests and recoveries to estimate the accuracy of a method was investigated while measuring the subject's own urinary and plasma creatinine concentrations and estimating his own glomerular filtration rate (see Appendix).

\section{DAY 5}

This day was devoted to testing the new worker's own precision and accuracy in laboratory techniques (see Appendix).

Statistical techniques were exploited, using the data collected during the one-week course, to assess precision and accuracy in mathematical form. Precision in measuring urinary creatinine concentrations was estimated from the differences between duplicates (days 1,2 , and 4 ) in $\mathrm{mg} / \mathrm{ml}$ from the formulae

$$
\text { Standard deviation }(\mathrm{SD})=\sqrt{\frac{\overline{\Sigma \mathrm{d}^{2}}}{2 \mathrm{n}}}
$$

and

$$
\text { coefficient of variation }(\%)=\frac{(\mathrm{SD})}{\overline{\mathrm{x}}} \times 100
$$

where $\Sigma \mathrm{d}^{2}=$ the sum of the squares of all the differences between duplicates, $\mathrm{n}=$ number of samples, and $\bar{x}=$ the mean urinary creatinine concentration $(\mathrm{mg} / \mathrm{ml})$ for all samples (Edwards and Whyte, 1958). Accuracy in measuring plasma creatinine concentrations was assessed by comparing the measured value obtained for the Versatol sample with the actual value quoted by the manufacturers for the batch used, and expressing this as a percentage recovery. Recoveries were also calculated from the subject's own plasma samples to which had been added sufficient creatinine solution to increase the measured value by $1 \mathrm{mg} \%$ (day 4). Programmes for automating the calculations for plasma and urinary creatinine concentrations and glomerular filtration rate (endogenous creatinine clearance) corrected for surface area and as a percentage of normal corrected for age and surface are awere devised for an electronic programmable imprinting calculator (Monroe EPIC 2000 or EPIC 3000 ) and the results rapidly and accurately determined.

Statistical analyses (mean, standard deviation, standard error of mean, coefficient of variation, Student's $t$ test of the significance of differences between means, linear regression equations, and coefficient of correlation) were all performed on results obtained for various tests during the week.

\section{Results and Discussion}

Results obtained are shown in Tables I-VII. No results appear for the acid-load tests and other renal function tests measured on day 3 as these were too extensive. The tests, however, are fully explained in the references given in the course programme.

Table I gives the average values for duplicate measurements for urinary creatinine concentrations for days 1 and 2. The letters (a), (b), and (c) refer to various procedures, which are listed under day 2 in the course programme. Table I shows, first, how the worker can compare his results with those of an independent laboratory (Renal Laboratory result) and thus gain confidence in his own ability: the closeness of the comparison can be seen in the mean values at the foot of the table. Thus, the mean value from the independent laboratory for day 1 was 0.93 $\mathrm{mg} / \mathrm{ml}$ compared with $0.89 \mathrm{mg} / \mathrm{ml}$ from the new research workers; for day 2 , the mean value was $0.94 \mathrm{mg} / \mathrm{ml}$ compared with $0.95,0.96$, and 0.98 $\mathrm{mg} / \mathrm{ml}$. Secondly, errors of technique occurred, as shown in the footnotes, but because of wide experience in the renal laboratories with the creatinine method the cause of the errors could usually be immediately determined. This instant feedback of corrective information, combined with knowledge of 
Table I Average values for duplicate measurement of urinary creatinine concentration $(\mathrm{mg} / \mathrm{ml})$ for days 1 and 2

See page 871 of text.

¿Duplicate reagent blank values were markedly different, perhaps due to one dirty test tube. The obviously incorrect result was disregarded. ${ }^{3}$ Wrong urine sample (sample 11 or 13 ) used by mistake.

'Spectrophotometer scale read wrongly: decimal point misplaced.

${ }^{5} \mathrm{HCl}$ accidentally omitted from Fuller's earth adsorption stage.

'Error made in calculations (reagent blank not subtracted from standard): corrected results, reading from above downwards, were $0.93,0.46$, $1 \cdot 00,0 \cdot 88$.

${ }^{7}$ With the exception of samples where comparable values were missing or erroneous $(n=21$ for day $1 ; n=13$ for day 2 ).

\begin{tabular}{|c|c|c|c|c|c|c|c|c|c|}
\hline $\begin{array}{l}\text { Research } \\
\text { Worker }\end{array}$ & $S . A .^{1}\left(M^{2}\right)$ & Time (min) & $\begin{array}{l}\text { Urine } \\
\text { Volume' } \\
(\mathrm{ml})\end{array}$ & $\begin{array}{c}P_{\mathrm{Cr}^{2}} \\
(m g \%)\end{array}$ & $\begin{array}{c}U_{\mathrm{Cr}^{3}} \\
(m g / m l)\end{array}$ & $\begin{array}{c}G F R^{4} \\
(\mathrm{ml} / \min \\
\left.17 \cdot 3 M^{2}\right)\end{array}$ & Age (years) & $\begin{array}{l}\text { Mean } \\
\text { GFR( } \% \text { of } \\
\text { normal })\end{array}$ & $\begin{array}{l}\text { Percentage } \\
\text { Recoverv } \\
\text { Plasma Versato I }\end{array}$ \\
\hline A.G. & $\begin{array}{l}1 \cdot 71 \\
1 \cdot 71\end{array}$ & $\begin{array}{l}201 \\
187\end{array}$ & $\begin{array}{l}140 \\
162\end{array}$ & $\begin{array}{l}0.89 \\
0.89\end{array}$ & $\begin{array}{l}1 \cdot 46 \\
1 \cdot 15\end{array}$ & $\begin{array}{l}115 \\
113\end{array}$ & 30 & 93 & 96 \\
\hline C.A. & $\begin{array}{l}1.63 \\
1.63\end{array}$ & $\begin{array}{l}180 \\
180\end{array}$ & $\begin{array}{l}132 \\
162\end{array}$ & $\begin{array}{l}0.82 \\
0.82\end{array}$ & $\begin{array}{l}1 \cdot 19 \\
0.95\end{array}$ & $\begin{array}{l}113 \\
111\end{array}$ & 20 & 85 & 100 \\
\hline R.G. & $\begin{array}{l}1.44 \\
1.44\end{array}$ & $\begin{array}{l}184 \\
187\end{array}$ & $\begin{array}{l}183 \\
197\end{array}$ & $\begin{array}{l}0.87 \\
0.87\end{array}$ & $\begin{array}{l}0.79 \\
0.81\end{array}$ & $\begin{array}{l}114 \\
112\end{array}$ & 21 & 86 & 101 \\
\hline E.C. & $\begin{array}{l}1 \cdot 54 \\
1 \cdot 54\end{array}$ & $\begin{array}{l}180 \\
180\end{array}$ & $\begin{array}{l}596 \\
112\end{array}$ & $\begin{array}{l}0.67 \\
0.67\end{array}$ & $\begin{array}{l}0 \cdot 23 \\
1 \cdot 20\end{array}$ & $\begin{array}{l}131 \\
126\end{array}$ & 22 & 99 & 97 \\
\hline J.C. & $\begin{array}{l}1.63 \\
1.63\end{array}$ & $\begin{array}{l}180 \\
180\end{array}$ & $\begin{array}{l}64 \\
74\end{array}$ & $\begin{array}{l}0.77 \\
0.77\end{array}$ & $\begin{array}{l}1.97 \\
1.63\end{array}$ & $\begin{array}{l}107 \\
120\end{array}$ & 24 & 89 & 98 \\
\hline L.S. & $1 \cdot 54$ & 189 & 186 & 0.61 & 0.89 & 161 & 20 & 124 & 94 \\
\hline
\end{tabular}

Table II Estimation of subjects' oun renal function $(G F R)$ on day 4

Surface area

Plasma creatinine concentration

Urinary creatinine concentration

‘Glomerular filtration rate, corrected for surface area, by the following formula: GFR $=\frac{173}{S A} \times \frac{\text { Urine Vol }}{\text { Time }} \times \frac{U_{\text {cr }}}{P_{\mathrm{Cr}}}$

${ }^{5}$ Glomerular filtration rate, expressed as a $\%$ of normal, and corrected for age and surface area by the following formula:

$\operatorname{GFR}(\%$ normal $)=\frac{\text { GFR } \times 115}{173-\text { age }(\text { years })}$

'Quality control test of accuracy of $\mathrm{P}_{\mathrm{Cr}}$ measurements. 
successful results, was thought to assist greatly the learning progress (Hilgard, 1956).

Table II shows the values obtained for the kidney function of each individual research worker. Formulae used to calculate the results are given in the footnotes and in the course programme. The degree of accuracy attained with the creatinine method is shown by the closeness of the duplicate estimations of the glomerular filtration rate and by the percentage recoveries obtained when the Versatol diagnostic reagent was measured (Table II). For the latter, values of 96 to 101 were recorded. The learning process here was assisted by the worker's interest in assessing his own kidney function.

Tables III, IV, V, and VI show the accuracy and precision which the new research worker could achieve during the course. Calculations were performed with the aid of a small desk-top computercalculator. In Table III correlation coefficients were estimated from the data to test the validity of the linear regression equations. These were highly significant $(\mathrm{P}<0.001$ : Moroney, 1956). The values for $\mathrm{m}$ were closely similar for different workers; provided that room temperature was constant throughout (Edwards and Whyte, 1958), this offered a further opportunity to assess and compare each individual's accuracy. The constant $\mathrm{c}$ in the equation agreed closely with the measured optical density of the reagent blank: this was the result desired, since the optical density of creatinine solutions and re-

\begin{tabular}{llllll}
\hline $\begin{array}{l}\text { Research } \\
\text { Worker }\end{array}$ & $y=m x+c^{1}$ & & & & $\begin{array}{l}\text { Optical } \\
\text { Density of } \\
\text { Reagent }\end{array}$ \\
\cline { 2 - 3 } \cline { 5 - 6 } & $\begin{array}{l}\text { Coefficient } \\
\text { of Correlation } \\
(\boldsymbol{r})\end{array}$ & $m$ & $c$ & $\begin{array}{l}\text { Blank } \\
\text { (compare } \\
\text { with } c)\end{array}$ \\
\hline A.G. & 0.9994 & 0.021 & & 0.164 & 0.162 \\
C.A. & 0.9999 & 0.020 & & 0.178 & 0.165 \\
E.C. & 0.9999 & 0.021 & & 0.110 & 0.104 \\
L.S. & 0.9999 & 0.021 & 0.127 & 0.117 \\
R.G. & 0.9927 & 0.021 & 0.130 & 0.114 \\
\hline
\end{tabular}

Table III Calculation of coefficient of correlation and linear regression equation for creatinine on day $5 a$

${ }^{1}$ Regression equation, where $y=$ optical density of creatinine solutions read at $490 \mathrm{~m} \mu$, using a water blank as reference; $x=\mathrm{vol}$ in $\mu l$ of creatinine solution $(1 \mathrm{mg} / \mathrm{ml})$. agent blank were measured using water as zero reference blank, and the value for the reagent blank was not subtracted before calculating the regression equations.

In Table IV the precision attainable by gravimetric means after a single pipetting was assessed by calibrating a $10-\mathrm{ml}$ bulb pipette; coefficients of variation of less than $0.2 \%$ were obtained for this method. By calculating standard deviations and coefficients of variation for all data (Tables IV, V, VI, and VII) the worker could assess his precision of measurement with a variety of methods and could thus gain confidence in his techniques. Such statistical exercises not only showed the new worker how to correlate data but also how to test the validity of results.

\begin{tabular}{llll}
\hline $\begin{array}{l}\text { Research } \\
\text { Worker }\end{array}$ & $\begin{array}{l}\text { Mean } \text { OD } \\
\text { Blank }\end{array}$ & $\begin{array}{l}\text { Standard } \\
\text { Deviation }\end{array}$ & $\begin{array}{l}\text { Coefficient of } \\
\text { Variation }(\%)\end{array}$ \\
\hline A.G. & 0.4521 & 0.0040 & 0.9 \\
C.A. & 0.4110 & 0.0060 & 1.4 \\
E.C. & 0.4473 & 0.0020 & 0.5 \\
L.S. & 0.4553 & 0.0108 & 2.3 \\
\hline
\end{tabular}

Table V Spectrophotometric precision of method using a $0.02 \mathrm{ml}$ constriction pipette

A similar exercise in statistics, to find the standard error of the method for measuring urinary creatinine from differences between duplicates, is shown in Table VII. These calculations showed the worker another method of assessing the precision of the method and his handling of it. In future work, this approach should greatly assist him to assess the accuracy and precision of any new method and to gain confidence in it.

\section{LEARNING PROCESS}

A number of principles upon which learning theorists might agree were found to be of use during this one-week course, and could be listed as follows (Hilgard, 1956):

1 Active participation by a learner was preferable to passive reception when learning, for example, from a lecture or a motion picture.

\begin{tabular}{|c|c|c|c|c|c|}
\hline Research Worker & $\begin{array}{l}\text { Mean Weight }(g) \text { of } \\
\text { Pipetted Samples of } \\
\text { Water }\end{array}$ & Standard Deviation & $\begin{array}{l}\text { Coefficient of } \\
\text { Variation }(\%)\end{array}$ & $\begin{array}{l}\text { Water Temperature } \\
\left({ }^{\circ} \mathrm{C}\right)\end{array}$ & $\begin{array}{l}\text { Calibration of Pipette } \\
(m l)\end{array}$ \\
\hline $\begin{array}{l}\text { R.G. } \\
\text { E.C. } \\
\text { J.C. } \\
\text { L.S. }\end{array}$ & $\begin{array}{l}9.9436 \\
9.9911 \\
9.9459 \\
9.9706\end{array}$ & $\begin{array}{l}0.0164 \\
0.0066 \\
0.0108 \\
0.0045\end{array}$ & $\begin{array}{l}0 \cdot 16 \\
0 \cdot 07 \\
0 \cdot 10 \\
0 \cdot 05\end{array}$ & $\begin{array}{l}25 \cdot 6 \\
26 \\
20 \\
24 \cdot 6\end{array}$ & $\begin{array}{r}9.9750 \\
10.0237 \\
9.9777 \\
9.9995\end{array}$ \\
\hline
\end{tabular}

Table IV Calibration of $10 \mathrm{ml}$ bulb pipette and calculation of precision of pipetting by a gravimetric method 


\begin{tabular}{|c|c|c|c|c|c|c|c|}
\hline \multirow{2}{*}{$\begin{array}{l}\text { Research } \\
\text { Worker }\end{array}$} & \multicolumn{3}{|c|}{ Constriction Pipette } & \multicolumn{3}{|l|}{ Micro-syringe } & \multirow{2}{*}{$t^{1}$ Value } \\
\hline & $\begin{array}{l}\text { Mean Optical } \\
\text { Density - } \\
\text { Reagent Blank }\end{array}$ & $\begin{array}{l}\text { Standard } \\
\text { Deviation }\end{array}$ & $\begin{array}{l}\text { Coefficient of } \\
\text { Variation }{ }^{2} \\
(\%)\end{array}$ & $\begin{array}{l}\text { Mean Optical } \\
\text { Density - } \\
\text { Reagent Blank }\end{array}$ & $\begin{array}{l}\text { Standard } \\
\text { Deviation }\end{array}$ & $\begin{array}{l}\text { Coefficient of } \\
\text { Variation }{ }^{2} \\
(\%)\end{array}$ & \\
\hline $\begin{array}{l}\text { C.A. } \\
\text { R.G. } \\
\text { J.C. }\end{array}$ & $\begin{array}{l}0.4109 \\
0.4549 \\
0.4396\end{array}$ & $\begin{array}{l}0.0082 \\
0.0026 \\
0.0049\end{array}$ & $\begin{array}{l}2 \cdot 0 \\
0 \cdot 6 \\
1 \cdot 1\end{array}$ & $\begin{array}{l}0.4008 \\
0.4304 \\
0.4250\end{array}$ & $\begin{array}{l}0.0040 \\
0.0104 \\
0.0038\end{array}$ & $\begin{array}{l}1 \cdot 0 \\
2 \cdot 4 \\
0 \cdot 9\end{array}$ & $\begin{array}{l}2 \cdot 51^{3} \\
6 \cdot 55^{4} \\
5 \cdot 70^{4}\end{array}$ \\
\hline
\end{tabular}

Table VI Comparison of constriction pipette and micro-syringe and use of Student's t test

${ }^{2}$ Student's $\mathrm{t}$ test (Moroney, 1956)

${ }^{2}$ Coefficient of variation $=\frac{\mathrm{SD}}{\mathrm{X}} \times 100 \%$

Probably significantly different $(P<0.05)$

‘Highly significant difference $(P<0.001)$

\begin{tabular}{llll}
\hline $\begin{array}{l}\text { Research } \\
\text { Worker }\end{array}$ & $\begin{array}{l}\text { Mean Urinary } \\
\text { Creatinine } \\
\text { Concentration } \\
(\mathrm{mg} / \mathrm{ml})\end{array}$ & $\begin{array}{l}\text { Standard } \\
\text { Deviation } \\
(\mathrm{mg} / \mathrm{ml})\end{array}$ & $\begin{array}{l}\text { Coefficient of } \\
\text { Variation }(\%)\end{array}$ \\
\hline A.G. & 0.882 & 0.018 & $2 \cdot 1$ \\
C.A. & 1.112 & 0.016 & 1.5 \\
R.G. & 0.978 & 0.022 & 2.3 \\
E.C. & 0.898 & 0.011 & 1.2 \\
J.C. & 0.967 & 0.019 & 2.0 \\
L.S. & 1.831 & 0.034 & 1.9 \\
\hline
\end{tabular}

Table VII Assessment of standard deviation of measuring urinary creatinine concentration ${ }^{1}$

${ }^{1}$ Standard deviation $=\sqrt{\frac{\overline{\Sigma \mathrm{d}^{2}}}{2 \mathrm{n}}}$ (see course programme for details)

2 Spaced or distributed recalls were advantageous in fixing material that was to be long retained.

3 Transfer to new tasks was better if the learner discovered relationships for himself, and had personal experience during learning of applying these principles in practice.

4 Meaningful materials and meaningful tasks were learned more readily than nonsense materials and more readily than tasks not understood by the learner.

5 Information about the nature of a good performance, knowledge of his own mistakes, and knowledge of successful results aided learning.

6 Tolerance of failure was best taught through providing a backlog of success, which compensated for any experience of failure.

7 A motivated learner acquired knowledge more readily than one who was not motivated. The relevant motives included both general and specific ones, for example, desire to learn, need for achievement (general), desire for a certain reward, or fear of a threatened punishment (specific).

8 Learning under the control of reward (for example, the sense of achievement attained on measuring one's own glomerular filtration rate) was usually preferable to learning under the control of punishment.

Correspondingly, learning motivated by success was preferable to learning motivated by failure.

THE INTEGRATION OF NEW WORKERS AND THE CREATION OF NEW WORKING RELATIONSHIPS WITHIN A DEPARTMENT

Any office, factory, or hospital is made up of a veritable checkerboard of 'territories'. Territorial factors may limit the ability of the new employee to perform his work efficiently so that a breadth of territory is considered necessary in his social and working environment from the start. The one-week course offers the new worker free access to all areas, techniques, and equipment. In addition, he meets the people with whom he will be working, and from whom he can receive help when difficulties arise.

A suitable language of communication with fellow workers was also learnt by the new employee during the one-week course: this language enabled him to recognize, and refer accurately to his new environment, to express his results in accordance with the standards and language set by the department, and to discuss his work freely with other employees.

The one-week introductory course therefore offers a means of establishing the research worker in his new surroundings, showing him the importance of precision and accuracy in his work, and initiating his integration among the other workers in the department. It has been successfully completed by many people with varying qualifications. We feel that it could be applied in principle to any laboratory, and the actual tests could be changed to suit individual requirements.

The authors wish to express their thanks to Dr A. Z. Györy of the same department for assistance with one-day renal function testing and measurement of renal acid-base regulation during an acid load, and 
to Dr W. McCarthy, senior lecturer, Sydney University Surgical Unit, Sydney Hospital, for his valuable criticism of the manuscript and for his exhilarating approach to medical education. The work was supported by the National Health and Medical Research Council of Australia.

\section{References}

Edwards, K. D. G., Stewart, J. H., Ashley, B. C. E., and Whyte, H. M. (1964). One-day renal function tests. Proc. Aust. Ass. clin. Biochemists, 1, 101-105.

Edwards, K. D. G., and Whyte, H. M. (1958). The measurement of creatinine in plasma and urine. Aust.J. exp. Biol. med Sci. 36, 383-394.

Geigy, J. R. (1962). Scientific Tables, Sixth Edition, edited by K. Diem (Documenta Geigy), Geigy Pharmaceuticals, Ardsley, New York.

Györy, A. Z., and Edwards, K. D. G. (1967). Simultaneous titrimetric determination of bicarbonate and titratable acid of urine. Aust. J. exp. Biol. med. Sci., 45, 141-144.

Györy, A. Z., and Edwards, K. D. G. (1968a). Sequential determination of urinary bicarbonate, titratable acid, ammonia, total acid and inorganic phosphate phosphorus by titrimetry using a single urine aliquot. (Abstr.) Aust. Ann. Med., 17, 85.

Györy, A. Z., and Edwards, K. D. G. (1968b). Renal tubular acidosis. Amer. J. Med., 45, 43-62.

Handbook of Chemistry and Physics (1955). 36th ed., p. 1962. Chemical Rubber Publishing Co., Cleveland, Ohio, USA.

Hilgard, E. R. (1956). Theories of Learning, 2nd ed. Appleton, New York.

Jörgensen, K. (1957). Titrimetric determination of the net excretion of acid/base in urine. Scand. J. clin. Lab. Invest., 9, 287-291.

Kanematsu Memorial Institute Annual Report (1965). Report for the Year 1965, Kanematsu Memorial Institute, Sydney Hospital, Sydney.

Moroney, M. J. (1956). Facts from Figures, 3rd ed. Penguin Books, Harmondsworth.

Pitts, R. F. (1963). Physiology of the Kidneys and Body Fluids. Year Book Medical Publishers, Chicago.

Pratt,D., McCredie, M., and Edwards, K.D.G.(1967). The effect of ionexchange resins, charcoal and delay-in-treatment on poisoning with a basic drug (mecamylamine) in rats. Med. J. Aust., 2, 349-351.

Steele, T. W., Edwards, K. D. G., and Györy, A. Z. (1968). One-day renal function tests in analgesic nephropathy in man: disturbances of G.F.R., urinary acidification and ammonium and citrate excretion. (Abstr.) Aust. Ann. Med., 17, 353.

Steele, T. W., Györy, A. Z., and Edwards, K. D. G. (1969). Renal function in analgesic nephropathy. Brit. med. J., 2, 213-216.

\section{Appendix}

\section{Day 1 (a)}

A brief introductory talk is given.

(b) After an introductory talk by the librarian, borrow two journals from the library; for example, Jörgenson (1957) and Edwards and Whyte (1958), and request the following reprints from the appropriate departmental secretary: Edwards et al (1964) and Györy and Edwards (1967). Borrow the following textbook, which is recommended for reading, 'Physiology of the kidneys and body fluids' by R. F. Pitts (chapters 5 and 11: 1963).

(c) Select four urine samples with different creatinine contents, previously measured by an independent laboratory (see Renal Laboratory
Result: Table I). Add, in duplicate and by constriction pipette, $0.02 \mathrm{ml}$ of each urine sample to $5 \mathrm{ml}$ aliquots (bulb pipette) of dilute alkaline picrate colour reagent $(10 \mathrm{ml} 0.75 \mathrm{~N} \mathrm{NaOH}$ and $10 \mathrm{ml}$ saturated picric acid made up to $100 \mathrm{ml}$ with distilled water). Also prepare a standard and a blank similarly in duplicate and continue according to the method described by Edwards and Whyte (1958). Calculate the values for urinary creatinine concentrations in duplicate using a desk-top electronic computercalculator.

\section{Day 2}

Further experience in pipetting and additional data for statistical analysis are gained by varying the method for estimating urinary creatinine as follows:

(a) Pipette in duplicate $0.02 \mathrm{ml}$ (constriction pipette) of each sample into $4 \mathrm{ml}$ (automatic syringe pipette) of distilled water and add $1 \mathrm{ml}$ (bulb pipette) of concentrated alkaline picrate solution $(10 \mathrm{ml}$ of $0.75 \mathrm{~N} \mathrm{NaOH}$ and $10 \mathrm{ml}$ of saturated picric acid). Read and calculate as before.

(b) Pipette in duplicate $0.02 \mathrm{ml}$ (constriction pipette) of each sample into $4 \mathrm{ml}$ (automatic syringe pipette) of distilled water and $1 \mathrm{ml}$ of $0.1 \mathrm{~N} \mathrm{HCl}$. Add approximately $100 \mathrm{mg}$ of Fuller's earth and proceed as for measuring serum creatinine (Edwards and Whyte, 1958).

(c) Make a 1 in 200 dilution of each urine sample in duplicate by pipetting $1 \mathrm{ml}$ (bulb pipette) into a $200 \mathrm{ml}$ volumetric flask and make up to the correct volume with distilled water; take $4 \mathrm{ml}$ (bulb pipette) aliquots of each dilution and add Fuller's earth and $\mathrm{HCl}$ as above.

\section{Day 3}

Details of tests performed on this day have been described by Edwards et al (1964), Györy and Edwards (1968b) and Steele et al (1969). In summary, have a self sample of blood collected and three self samples of urine (two three-hour and one two-hour timed urine samples), after having a pitressin injection and taking an oral acid load (ammonium chloride, $0 \cdot 1 \mathrm{~g} / \mathrm{kg}$ ). Study own glomerular filtration rate and renal tubular functions involved in acid-base balance. Most measurements, such as full blood count, serum urea nitrogen, and electrolytes and urinary and plasma creatinine concentrations, are done in a routine pathology laboratory and the renal laboratory, but perform the acid load measurements on the same day as the collection, using the automatic titration method of Györy and Edwards (1967 and 1968a and b). Full details of laboratory procedure can be obtained from these references. 
Set aside overnight aliquots of urine and serum $(16 \mathrm{ml})$ in the refrigerator for measurement of creatinine the next day.

\section{Day 4}

Measure own urinary creatinine in duplicate and on each sample using the method already described (Day 1). Before measuring plasma creatinines, precipitate plasma proteins by pipetting $2 \mathrm{ml}$ of plasma into a plastic stoppered centrifuge tube; add $4 \mathrm{ml}$ distilled water; mix and add $2 \mathrm{ml} 6 \%$ sodium tungstate hexahydrate; mix and add $2 \mathrm{ml} 0.67$ $\mathrm{N} \mathrm{H}_{2} \mathrm{SO}_{4}$; shake several times in 10 minutes and then centrifuge at $3,000 \mathrm{rpm}$ for 10 minutes. To do recoveries on the plasma samples, substitute $4 \mathrm{ml}$ $0.5 \mathrm{mg} \%$ creatinine solution for $4 \mathrm{ml}$ distilled water in the above precipitation mixture. To check further the accuracy of the method, measure the creatinine content of a reconstituted sample of Versatol (Warner-Chilcott diagnostic reagent of known creatinine content). Use the method of Edwards and Whyte (1958) to measure the creatinine in $5 \mathrm{ml}$ aliquots of the protein-free filtrates. Also record own height, weight, and age, and estimate surface area, for example, from a Dubois and Dubois nomogram (Documenta Geigy Scientific Tables, 1962). Calculate, from the results obtained for plasma and urinary creatinine, a value for glomerular filtration rate; correct for surface area and age using the following formula: for

$\operatorname{GFR}(\%$ of normal age and SA $)=\operatorname{GFR}(\mathrm{ml} / \mathrm{min}) \times$ $\frac{1 \cdot 73}{\text { SA }\left(\mathrm{m}^{2}\right)} \times \frac{115}{173-\text { age }(\mathrm{yr})}$.

\section{Day 5}

Pipette $10,20,30,40$, and $50 \mu l$ of a standard creatinine solution $(1 \mathrm{mg} / \mathrm{ml})$, in duplicate, with a Hamilton 50 microlitre syringe into $5 \mathrm{ml}$ aliquots of dilute alkaline picrate solution. Calculate the regression coefficient and equation of the line comparing optical densities to volumes of sample (Moroney, 1956).

Calibrate a $10 \mathrm{ml}$ bulb pipette by measuring $10 \mathrm{ml}$ of water, of known temperature, 10 consecutive times into a $200 \mathrm{ml}$ stoppered weighing flask, weighing before commencing pipetting and after each addition. Calculate the mean, standard deviation, and coefficient of variation of the readings of weight and convert the mean to volume from the specific gravity of water at the measured temperature (Handbook of Chemistry and Physics, 1955).

Measure $1520 \mu$ l aliquots of standard creatinine solution $(1 \mathrm{mg} / \mathrm{ml})$ using a $0.02 \mathrm{ml}$ constriction pipette into $5 \mathrm{ml}$ lots of colour reagent; similarly measure $20 \mu \mathrm{l}$ aliquots using a Hamilton 50 microlitre syringe. Calculate the mean, standard deviation, and coefficient of variation for each group of replicates and apply Student's t test to test for significance of difference between the means for each group (Moroney, 1956). 